\title{
Keyword Based Learning (KBL): a novel teaching/learning strategy
}

\author{
Satheesha Nayak $B^{1}$, Soumya $K V^{2}$
}

\begin{abstract}
In Medical Education today, the focus is mainly on the "student-centred" teaching/learning strategies. We tried a novel, teaching/learning strategy called 'keyword based learning' for first year medical students. The strategy is characterized by giving a series of keywords to students and asking them to learn the related topic and arrive at the learning objectives related to the keywords given. Student feedback was collected and $80 \%$ of the students were positive about this strategy.
\end{abstract}

Keywords: keyword based learning, anatomy, active learning, medical education, problem based learning

\section{Introduction}

A novel, active teaching/learning strategy called 'keyword based/learning' (KBL) is explained. This strategy was tried on first year medical students during their neuroanatomy practical classes. The KBL strategy is characterized by giving a series of keywords to students and asking them to learn the topic related to the keywords. This strategy is believed to keep the students engaged in learning actively in small groups just in a similar manner as in a problem-based learning (PBL). PBL is an active learning strategy where students work in small groups. Problem-based learning was first introduced in medical education from McMaster University in 1969 (Neville, 2009). It has undergone radical innovations in recent years and several hybrids of traditional and PBL curricula are being tried now. At McMaster

\footnotetext{
${ }^{1}$ Department of Anatomy, Melaka Manipal Medical College (Manipal Campus), International Centre for Health Sciences. Manipal University, Manipal, INDIA. 576104

${ }^{2}$ Department of Mathematics, Manipal Institute of

Technology, Manipal University, Manipal, INDIA. 576104.

Corresponding author:

Professor and Head, Department of Anatomy

Melaka Manipal Medical College (Manipal Campus)

International Centre for Health Sciences

Manipal University

Madhav Nagar, Manipal

Udupi District, Karnataka State, INDIA

576104

E-mail: nayaksathish@yahoo.com
}

University, it was felt that lecture was not the most satisfactory means of providing a contemporary learning environment (Pallie et al., 1987). Therefore, the class was divided into small groups of five or six students and a tutor was assigned to each group. This constituted the tutorial group and that was the backbone of the PBL program. In 1974, a new Medical Faculty at the University of Limburg, Maastricht, Netherlands adopted the McMaster model to suit the Dutch situation. Since then several medical schools around the world have undertaken the curriculum transplant using PBL. In a PBL curriculum, learning happens through "problems" or "triggers". A clinical problem is given to small groups of students and the students achieve the learning objectives using the problem. PBL tutorial involves the following steps. i.e., defining a problem, identifying the unfamiliar terms, finding the issues, making hypothesis, framing the learning objectives, self-directed learning and presentation/discussion in small groups. PBL provides integration between various preclinical, Para-clinical and clinical disciplines. It is very difficult to have PBL sessions involving learning objectives of only one discipline. In other words, it is difficult to conduct a PBL session involving only anatomy, only physiology or only biochemistry learning objectives. KBL can be tried in any discipline independently. $\mathrm{KBL}$ involves only four steps; getting the keywords from the teacher, reading the material related to the keywords, arriving at the learning objective, 
and presenting the learning objectives to the teacher. Advantages of the KBL method over the PBL method is that it can be implemented in theory or to practical classes, it can be tried in individual disciplines and it is not very stressful to students since they have to frame the learning objectives from only one discipline. In PBL the teacher is "actively passive" or "passively active" and is known as tutor. The teachers do not teach the tutorial process. In KBL the tutor has both roles. At first the teacher will watch the group proceedings and finally explains the intended learning objectives to the students. KBL strategy can be implemented widely in any existing conventional or hybrid curricula.

\section{Background}

At Melaka Manipal Medical College (Manipal Campus) Manipal, the anatomy curriculum is divided into four blocks, each ten weeks long. The neuroanatomy is taught / learnt in the fourth block. The neuroanatomy teaching includes 4 lecture classes one hour each per week and 4 practical classes 2 hours each per week. The class is divided into smaller batches consisting of 18 students in a group for practical classes. During practical classes the teachers dissect and demonstrate the parts of the central nervous system to the students. Usually, in the first 30 minutes of a practical class, students revise the previous day's topics, in the following one hour, the teachers teach the day's topic and in the last 30 minutes the students revise the day's topic. $\mathrm{KBL}$ strategy was tried in the first 30 minutes of a practical class.

\section{Methodology:}

At the beginning of the class, the small group of 18 students were given a series of keywords as shown in the Table 1. The learning objectives were not given to them. Each student in a small group (having 18 students in a group around a dissection table) was asked to use textbook and locate those keywords in their book and read the related topics individually. After reading the book, the students were instructed to discuss the keywords among the small group members and to arrive at the learning objectives. During this discussion, the teacher was nearby to ensure all 18 students participated actively in the reading and discussion assignments. After this, one of the group members (randomly selected by the teacher) was asked to present the intended learning objectives of the day to their group in the presence of the teacher. The teacher then explained to the students how to link the keywords with one another properly and how to arrive at the learning objectives of the day. Following this, the teacher explained in detail, the topic of that day to the students. After the KBL session, the teacher asked the students to give an informal oral feedback about their learning experience. The opinions of the students were noted down and compiled.

\section{Observations/Results}

Generally the students welcomed this type of learning; 144 students participated in the activity and most of them (80\%) liked it. They said it was "challenging" and it "engaged' them well in the learning process. Only a small portion $(20 \%)$ of them said it was "difficult" and they were "lost". The students felt that KBL could be a good "review tool" as it could make them think better on already learned topic. The students stated that it is difficult to find out the intended learning objectives using the given keywords, when they did not have any prior knowledge about the topic. The class requested either $\mathrm{KBL}$ or other active learning methods which could stimulate their thinking.

\section{Discussion}

Students can learn better and feel good when they actively engage themselves in the learning activities. The student opinions clearly indicated that KBL kept them engaged in their learning. In the past we had tried some innovative teaching/learning strategies which were well appreciated by the students (Satheesha, 2005; Satheesha, 2009; Satheesha, 2010). KBL is also an innovative method of teaching. $\mathrm{KBL}$ is a novel strategy which can keep students engaged in learning.

It provides opportunity to do self-directed learning and small group activities in a similar manner to that of PBL. This strategy could be used in teaching any subject and could be used for teaching new topics or for reviewing the previously learnt topics. Though the KBL was tried in practical classes, the strategy could be used in the theory classes too. In the current case, the $\mathrm{KBL}$ strategy was used directly for the day's topic. It is possible to give the keywords in advance and hold discussions on another day. This gives student ample time to find out the meanings of the words 
Table1: Learning objectives and related keywords

\begin{tabular}{|c|c|c|}
\hline Set no. & Intended learning objectives & Keywords \\
\hline 1 & $\begin{array}{l}\text { Origin, course, termination, functions } \\
\text { and clinical anatomy of corticospinal } \\
\text { tract }\end{array}$ & $\begin{array}{l}\text { Precentral gyrus, internal capsule, crus cerebri, } \\
\text { lateral funiculus of spinal cord, anterior horn cells, } \\
\text { corona radiata, pyramid of medulla, basilar part of } \\
\text { pons }\end{array}$ \\
\hline 2 & $\begin{array}{l}\text { Lateral medullary syndrome; cause, } \\
\text { structures affected and symptoms }\end{array}$ & $\begin{array}{l}\text { Posterior inferior cerebellar artery, medulla } \\
\text { oblongata, vestibular nuclei, nucleus ambiguus, } \\
\text { spinal tract of trigeminal nerve, inferior cerebellar } \\
\text { peduncle, dysphagia, dysarthria, atonia, Horner's } \\
\text { syndrome }\end{array}$ \\
\hline 3 & $\begin{array}{l}\text { Origin, course, termination and functions } \\
\text { of auditory pathway }\end{array}$ & $\begin{array}{l}\text { Medial geniculate body, superior olivary nucleus, } \\
\text { superior temporal gyrus, lateral lemniscus, organ } \\
\text { of corti }\end{array}$ \\
\hline 4 & $\begin{array}{l}\text { Basal nuclei; parts, functions, } \\
\text { connections and disorders }\end{array}$ & $\begin{array}{l}\text { Corpus striatum, putamen, globus pallidus, } \\
\text { Parkinson's disease, substantia nigra, chorea, } \\
\text { athetosis, hypertonia, resting tremors, rigidity, } \\
\text { internal capsule, external capsule, ansa } \\
\text { lenticularis }\end{array}$ \\
\hline 5 & $\begin{array}{l}\text { Cerebrospinal fluid; formation, } \\
\text { circulation, drainage and applied } \\
\text { anatomy }\end{array}$ & $\begin{array}{l}\text { Superior sagittal sinus, subarachnoid space, } \\
\text { foramen of Luschka, cerebral aqueduct, lateral } \\
\text { ventricle, choroid plexus, arachnoid villi }\end{array}$ \\
\hline 6 & $\begin{array}{l}\text { Internal capsule; parts, fibres passing } \\
\text { through, relations, blood supply and } \\
\text { clinical anatomy }\end{array}$ & $\begin{array}{l}\text { Genu, contralateral hemiplegia, lentiform nucleus, } \\
\text { thalamus, superior thalamic radiation, } \\
\text { corticospinal tract, frontopontine fibres, optic } \\
\text { radiation, acoustic radiation, anterior choroidal } \\
\text { artery, middle cerebral artery }\end{array}$ \\
\hline
\end{tabular}

Note. Each set of keywords was given to a small group of students during a specific 2 hour practical class.

and relate them to each other and find out the intended learning objective. In our setting, it was noticed that all the students participated actively in the learning process and contributed significantly to group activities. This strategy kept the students active and made them think. They discussed about the keywords and objectives with their peers, use their textbooks and their notes. In problembased learning (PBL), a clinical problem is given as a learning trigger but in $\mathrm{KBL}$ the keywords are given as triggers to initiate the process of thinking. If we use proper clinical terminologies as keywords, $\mathrm{KBL}$ could be as effective as or even better than PBL.

\section{References}

Neville, A.J. (2009) Problem-Based Learning and Medical Education Forty Years On, Medical Principles and Practice, 18, pp. 1-9.

Pallie, W. \& Carr, D.H. (1987) The McMaster education philosophy in theory practice and historical perspective, Medical Teacher, 9, 1, pp. 59-71.

Satheesha, B. Nayak. \& Soumya, Kodimajalu. (2010) Progressive Drawing - A Novel "lidopener" and "Monotony-breaker", Anat Sci Educ, 3, pp. 326-329.

Satheesha. \& Soumya, K.V. (2009) A simple model to demonstrate the movements and axes of the eyeball, Adv Physiol Educ, 33, pp. 356-357.

Satheesha, N.B., Somayaji., S.N. \& Ramnarayan K. (2005) Blunder lecture - An innovative method of teaching, Adv Physiol Educ, 29, pp.130-131. 